\title{
Performance Evaluation of Solar Water Pumping System
}

\author{
Priyanka $^{1}$, V. Raghavendra ${ }^{2} *$, Vijaykumar Palled ${ }^{2}$ and M. Veerangouda ${ }^{2}$ \\ ${ }^{1}$ College of Agriculture Engineering, UAS Raichur-584104, Karnataka, India \\ ${ }^{2}$ Department of Farm Machinery and Power Engineering, College of Agriculture \\ Engineering, UAS Raichur-584104, Karnataka, India \\ *Corresponding author
}

\begin{abstract}
A B S T R A C T
The use of photovoltaic (PV) array for pumping water is one of the most promising techniques in solar energy applications. In this paper design and performance analyze of

Keywords

Solar, Pumping

system, Solar

intensity, Solar radiation

Article Info

Accepted:

04 April 2018

Available Online:

10 May 2018

solar water pumping system is presented for college of Agricultural engineers UAS campus conditions. The solar pumping system consists of 32 modules of 255.8 watts each and $7.5 \mathrm{hp} \mathrm{DC}$ centrifugal mono block pump. The system was tested for its performance in terms of variation is in discharge due to change in solar testing. It was observed during normal climatic conditions the PV array produced power in the range of 7051.40 watts to 7848.22 watts from 10:30 am to $4: 30 \mathrm{pm}$ in the month of December 2014. It was observed that reduction in power generation in the range of $10.16 \%$ during noon conditions. PV array produced maximum power of 7848.22 watts $(12: 30 \mathrm{pm})$ while, Vmp and Imp of 490.82 volts and 15.99 amps respective. We have observed in the morning conditions that pump delivered discharge of $33.40 \mathrm{~m}^{3} / \mathrm{h}(10.30 \mathrm{am}-11: 30 \mathrm{am})$ of the head of $22.8 \mathrm{~m}$. It was observed that, in noon conditions pump delivered discharge of $41.82 \mathrm{~m}^{3} / \mathrm{h}(12: 30 \mathrm{pm})$ at the head of $22.8 \mathrm{~m}$ and the pumping efficiency was measured of $66.06 \%$. It was observed that, power output from the solar array increases as solar intensity increases. So increase in the power output was in the range from 7051.40 to 7848.22 watts.
\end{abstract}

\section{Introduction}

Agriculture in India has a significant history. Today, India ranks second worldwide in farm output. Agriculture and allied sectors like forestry and fishery accounted for $16.6 \%$ of the GDP in 2009. About 50\% of the people in India get employment from the agriculture. So, we should have very consciousness to develop agriculture. Thus solar water pumping becomes a socially and environmentally attractive technology to supply water. Especially, it is needed for water supply in remote locations which are beyond the reach of power line. Solar energy in particular, has such an established pattern that with an appropriate harnessing technology, it is possible to get considerable part of the world's energy needs from it. Solar energy is indeed the energy that is derived directly from the sunshine. The sun is the centre of the solar system with which our life and welfare and that of livestock, agricultural and botanical needs of all depends on for survival. Solar energy is very pure and inexhaustible. At present the most successful requirements of 
solar energy seems to be supply of solar water pump, space heating and cooling as well as generating of electricity etc., of these many uses of solar energy, pumping process is one which has been exploited most. It is now being accepted as a practical way of providing domestic water pumping system in Japan, Israel, U.S., India and some countries in Latin America. To develop agriculture, we should take care of plants. About $90 \%$ of the plant body consists of water. Due to unavailability of energy resources, we are unable to supply water to the crops. But, we can supply water at all time by solar energy. The amount of solar energy available during sunshine hours (8hrs) is $60 \times 10^{15} \mathrm{Wh} /$ day. If we use $5 \%$ of available energy it is 60 times the world energy requirement. Water pumping has a long history so many methods have been used to pump water. But, solar pumping is reliable. The use of photovoltaic cell is appropriate because of often relationship between water requirement and solar energy available. During hot season water requirement increases and also solar energy will be available at higher level. Hence, keeping the above in view this research topic has been undertaken with following objectives

To design and development of solar water pumping system

To evaluate the performance of developed solar water pumping system

Abdul kadir and Muhammadu (2012) developed solar water pumping system. They found that a flat plate solar generates vapour and its pressure is adequate to pump water. It shows that the pump can lift 2litres $\left(0.02 \mathrm{~m}^{3}\right)$ of water per cycle with volumetric flow rate of $0.000333 \mathrm{~m}^{3} / \mathrm{s}$ for $2 \mathrm{~m}$ discharge head and the pump has an overall efficiency of 53\%.

Brion D. Vick and R. Nolar Clark (2010) compared the performance evaluation of wind electronic water pumping system and solar PV water pumping system. They found that wind electric water pumping system is suitable for higher water pumping depth $(30 \mathrm{~m})$.

Hegazi et al., (2010) fabricated and evaluated solar powered irrigation pump. They found that pump efficiency decreases as head increases. They came to know that pump efficiency was below $40 \%$ when head is at $4 \mathrm{~m}$.

Abu-Aligah (2010) designed photovoltaic water pumping system and compared it with diesel powered pump. They analysed output of solar pump is mainly depend on correct design of solar panel system.

Pawan Kumar et al., (2013) observed the performance analysis of photovoltaic based submersible water pump. In their study, they found that maximum discharge was obtained in the noon at $12 \mathrm{pm}$ for $2 \mathrm{hp}$ DC motor operated by 10 pannels of each $225 \mathrm{~W}$ and power output 75 to $85 \mathrm{~W} / \mathrm{m}^{2}$.

Rajib Baran Roy (2012) designed and analyzed the performance of the solar PV DC water pumping system in Bangladesh. In his study, he found that, electricity will get lost in future 6 to 7 years. It has been found that, solar pumping can be done sufficiently 4.5 $\mathrm{kWh} / \mathrm{m}^{2}$.

Shiv Lal et al., (2013) Analysed TechnoEconomic feasibility of solar photovoltaic based submersible water pumping system for rural areas of Rajasthan. In this study, they found that solar photo voltaic water pumping system can replace fossil fuels $100 \%$. They mentioned the saving of $\mathrm{CO}_{2}$ emission by $14977.57 \mathrm{~kg} /$ year.

Sui tha sung and Misandar Mon (2013) designed and evaluated the solar water pumping system for rural families. In this 
experiment they found that PV water pumping systems are well suited to remote applications because of their inherent automatic features on/off switching due to their electronic control.

Maurya et al., (2013) analysed numerical stimulation and design parameters in solar photovoltaic water pumping system. They studied relations between array power and Borehole depth in Nigeria. The efficient water pumping is dependent on data collection from meteorological department.

\section{Materials and Methods}

A study was undertaken on design, performance evaluation of solar water pumping system. This chapter deals with the materials used and methods followed in conducting research work of performance evaluation of solar water pumping system. The main emphasis of the study was to evaluate solar water pump by measuring solar intensity, output voltage (V), current (A), Times (S) and computation discharge rate (lit/h).

The performance of solar photovoltaic powered water pumping system was evaluated. In this chapter the details of materials and methods used in the test are discussed. The solar photovoltaic of total capacity $8185.6 \mathrm{~W}$ (32 panels of $255.8 \mathrm{~W}$ each) has been purchased and installed at the center and were used to generate the power to run motor (DC) pump. DC Ammeter, multimeter, thermometer and solar intensity recorder were used to measure DC current, DC voltage, ambient temperature $\left({ }^{\circ} \mathrm{C}\right)$ and solar intensity $\left(\mathrm{W} / \mathrm{m}^{2}\right)$ respectively.

The experiment was conducted at the department of farm machinery and power engineering, college of Agricultural Engineering, Raichur, Karnataka. Raichur is situated on the latitude of $16^{\circ} 15^{\prime}$ north, longitude of $77^{\circ} 21^{\prime}$ east and at an elevation of 389 meters above mean sea level which is considered as North Eastern Dry Zone of Karnataka.

\section{PV controller}

The controller has two primary functions. First, it monitors the characteristics of the electricity being produced by the PV panels (volts and amps) and electronically modifies these values to enable the pump to run longer and more efficiently. Secondly, the controller is an electronic switch to control when the pump goes on and off. The controller monitors electricity from the PV panels, the water level in the well, and the water level in the tank to ensure efficient and safe pump operation. The photovoltaic controller works as a voltage regular.

A photovoltaic (PV) powered solar controller uses solar electricity produced on-site to run the pump. The primary function of a controller is to prevent the battery from being overcharged by the array. Some PV controllers also protect a battery from being overly discharged by the DC load. It balances entire system voltage and optimises system performance. The most practical benefit of a PV powered controller is the resultant simplicity of the overall system.

\section{Pump cable and ground wire}

Power wiring in conduit is installed from the solar array to the controller. Control wiring in conduit is installed from the controller to the float switch in the tank. Electrical wiring is installed from the pump in the well up to the controller. It used to connect the pump to the solar array. It must be sized properly to minimize line losses. Ground all equipment because water pumps attract lightening due to the excellent ground they provide. Locating 
arrays on high spots are avoided. Consider electric lightning rods on high ground around the pump to attract lightning away from the pump.

\section{Safety disconnects}

Mathematical switches to manually shut off electricity in case of an emergency or maintenance. These switches usually installed between the solar panels and the controllers and between the controller and the pump.

\section{Orientation and direction of the PV array}

Orientation of the PV array is one of the most important aspects of the site assessment. The PV array is positioned in such a way that the sunlight is utilized to its maximum that is true south direction. The ideal orientation for panels is south as they will be exposed to the sun for the maximum length of time during daylight hours, although other orientations still produce considerable amounts of power and attract significant tariff income. The local declination which depends on the location and changes with the times should, however, be taken into account.

\section{Determination of tilt angle}

The tilt angle was selected in accordance with the latitude of the location. Latitude of Raichur is $16^{\circ} 15^{\prime} \mathrm{N}$, therefore solar PV array was tilted at this angle.

\section{Measurements of current and voltage}

The current I (A) and Voltage (V) generated by the PV array under both tracked and nontracked condition was recorded every hour of the sunny day from 10:30 am to 04:30 pm using DC ammeter. To measure the output current and voltage of the PV array the DC ammeter was connected directly to the power supply terminals of the PV array.

\section{Power output}

The power outputs from the solar photovoltaic panel on a typical sunny day in the month December 2014 were recorded. The product of voltage and current generated from the SPV panel gives the power output in terms of watt.

Power $(\mathrm{P})=$ Voltage $(\mathrm{V}) \mathrm{X}$ Current $(\mathrm{I})$

Where,

$\mathrm{P}=$ output power of SPV, watts

$\mathrm{V}=$ voltage, volts

$\mathrm{I}=$ current, amps

\section{Discharge (Flow rate) of the pump}

Volume of water delivered by pump per unit time $\mathrm{m}^{3} / \mathrm{h}$ or $\mathrm{m}^{3} / \mathrm{sec}$. The discharge of the DC pump used in the test was measured by volumetric method by collecting the water in 25 liters container and the subsequent time taken to fill the container was recorded using stopwatch. The same was repeated for five trails and the average of five trails was considered. The same method was carried out under both non-tracked and tracked conditions.

$\mathrm{Q}=$ amount of water collected (liters)/time taken (sec)

\section{Results and Discussion}

The performance of solar pumping array has been evaluated under normal climatic conditions. To understand correct mechanism of change in one parameter causes other to change. We have to plot the graphs as follows.

\section{Variation of voltage and current}

The variation of voltage and current with respect to solar intensity were presented in figure 1 corresponding voltage and current 
distribution curve has been plotted. However, corresponding variation in voltage produced was in the range from 490.82 to 550.89 volts and correspondence variation in current generated was in the raise of 12.80 to 15.99 amps.

\section{Variation of DC power output with respect to input solar radiation}

The variation of DC output power with respect to solar intensity were presented in the figure 2 range corresponding DC output power v/s solar radiation graph is plotted. The DC output power will be in the range of 7051.40 to 7848.22 watts for corresponding change in solar intensity in the range of 476 to 834 $\mathrm{W} / \mathrm{m}^{2}$.

\section{Variation of temperature with respect to} input solar radiation

The radiations of Temperature with respect to solar intensity were presented in the figure 3. Corresponding Temperature V/S input solar radiation graph is plotted. The Temperature valves will be in the range of 29.38 to 33.33 ${ }^{0} \mathrm{C}$ for corresponding change in Solar Intensity in the range of 476 to $834 \mathrm{~W} / \mathrm{m}^{2}$

\section{Variation of DC power output power with respect to temperature}

The variations of output power with respect to temperature were presented in figure 4. Corresponding output power v/s temperature graph is plotted. The output power in the range of 7051.40 to 7848.22 watts for corresponding change in temperature range of 29.38 to $33.33{ }^{0} \mathrm{C}$.

\section{Variation of discharge with respect to solar intensity}

The variations of discharge with respect to solar intensity were presented in figure 5 and corresponding discharge v/s solar intensity graph is plotted. Discharge produced in the range 48.12 to $51.50 \mathrm{~m}^{3} / \mathrm{h}$ for corresponding change in Solar Intensity in the range of 476 to $834 \mathrm{w} / \mathrm{m}^{2}$

\section{Variation of discharge with respect to relative humidity}

The variations of discharge with respect to relative humidity were presented in the figure 6. Corresponding discharge v/s relative humidity graph is plotted. The discharge produced in the range of 48.12 to $51.50 \mathrm{~m}^{3} / \mathrm{h}$ for corresponding change in Relative Humidity in the range of 32.38 to $40.56 \%$

By above these curves, we can evaluate the performance of photovoltaic module. The total electric power output of a photovoltaic module is equals to its operating voltage multiplied by its operatives current.

The output characteristics of any given module were characterized by a performance vies called an $\mathrm{I}-\mathrm{V}$ curve that shows relationship between current and voltage output.

The print labeled Vmp and Imp was the operating point at which the maximum output was produced by the module at operating conditions indicated for that curve. The voltage at the maximum power plant could be determined by extending a vertical parallel from the curve downward to read a value on the horizontal voltage scale. The relation between current and voltage in the polynomial form below,

$$
Y=0.0815^{x^{2}}-6.0137 x+110.4
$$

The correlation coefficient between current and voltage was 0.9452 . As it was maximum than 0.90 It shows perfect correlation between them. 


\section{Components of SPV water pumping system}
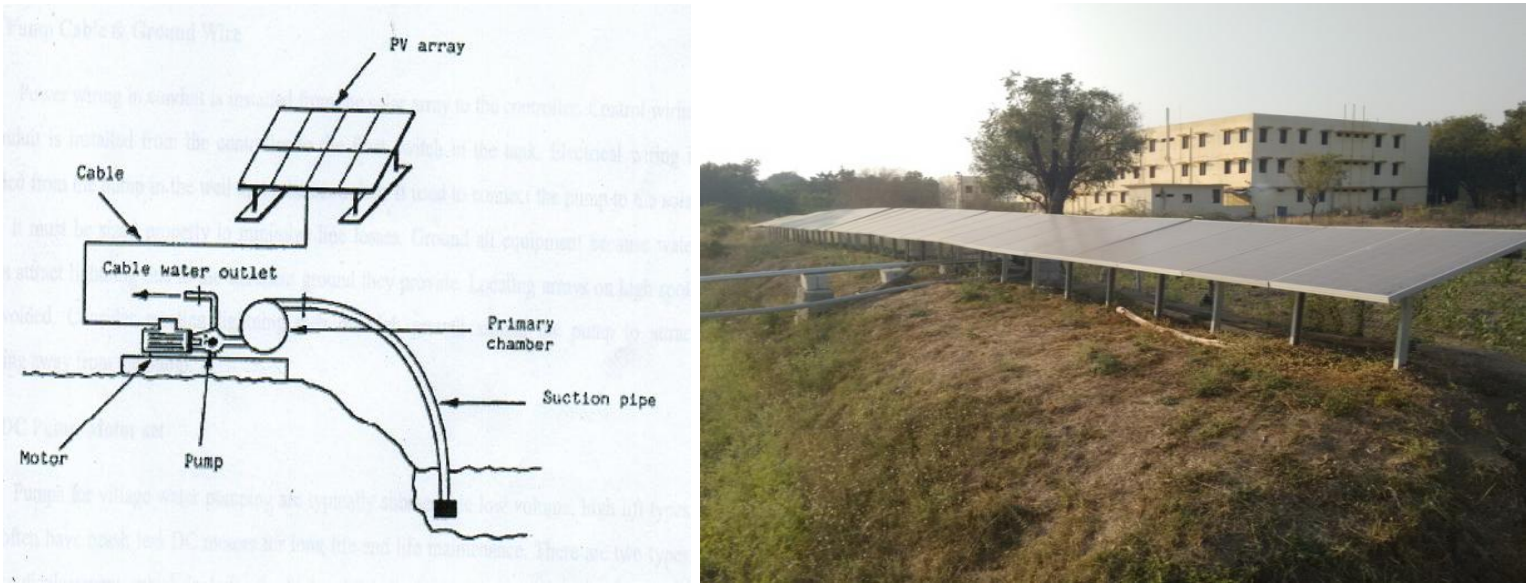

Fig.1 Variation of voltage and current
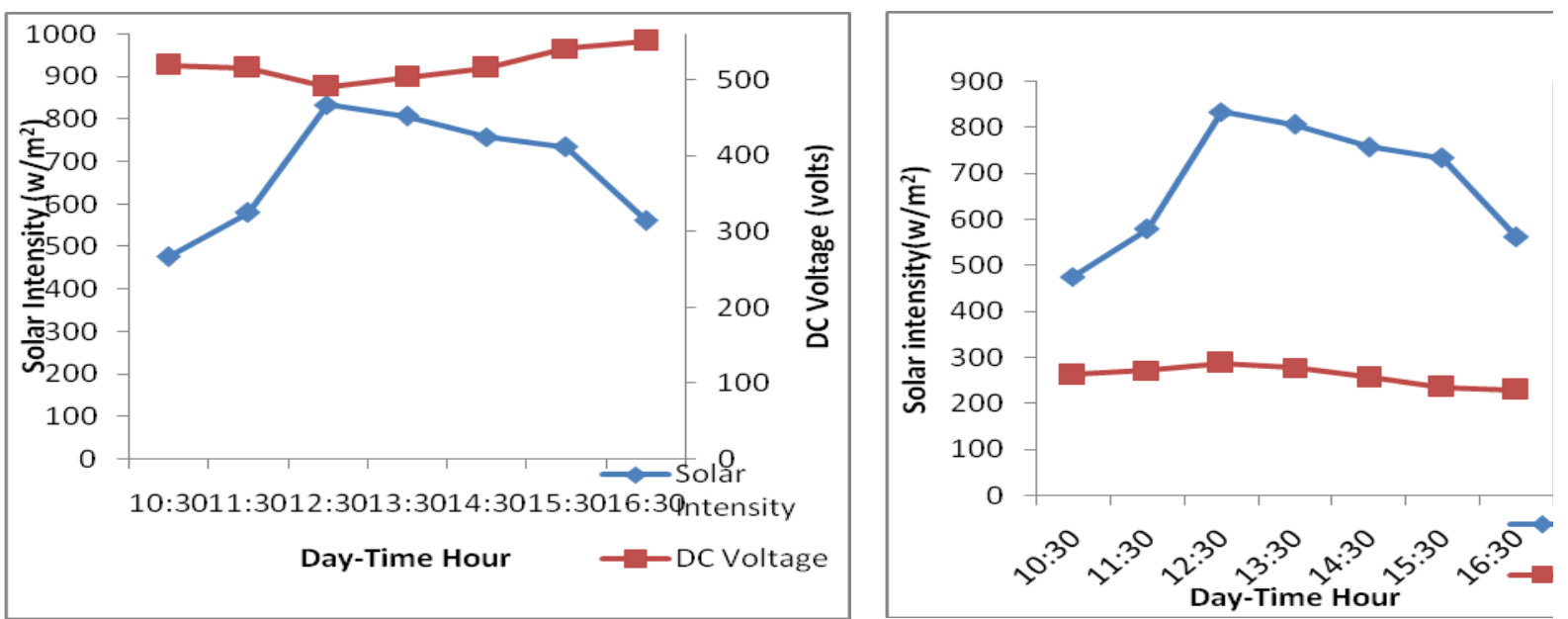

Fig.2 Variation of DC power output with respect to input solar radiation

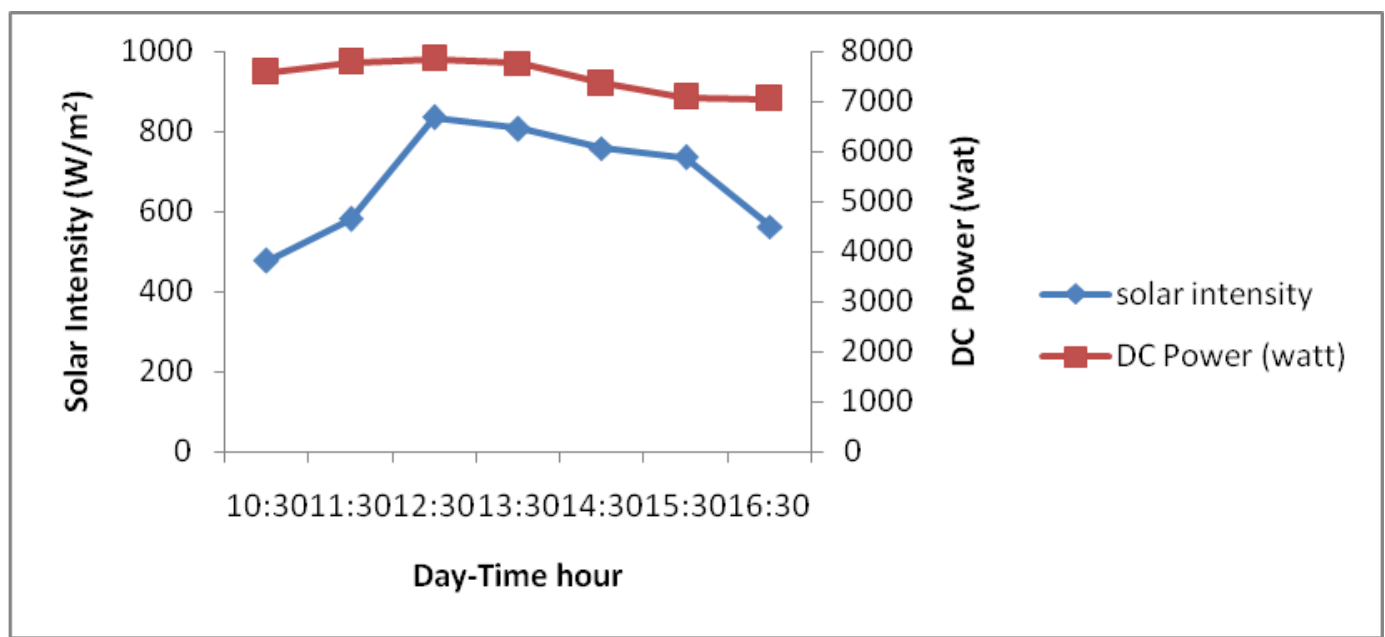


Fig.3 Variation of temperature with respect to input solar radiation

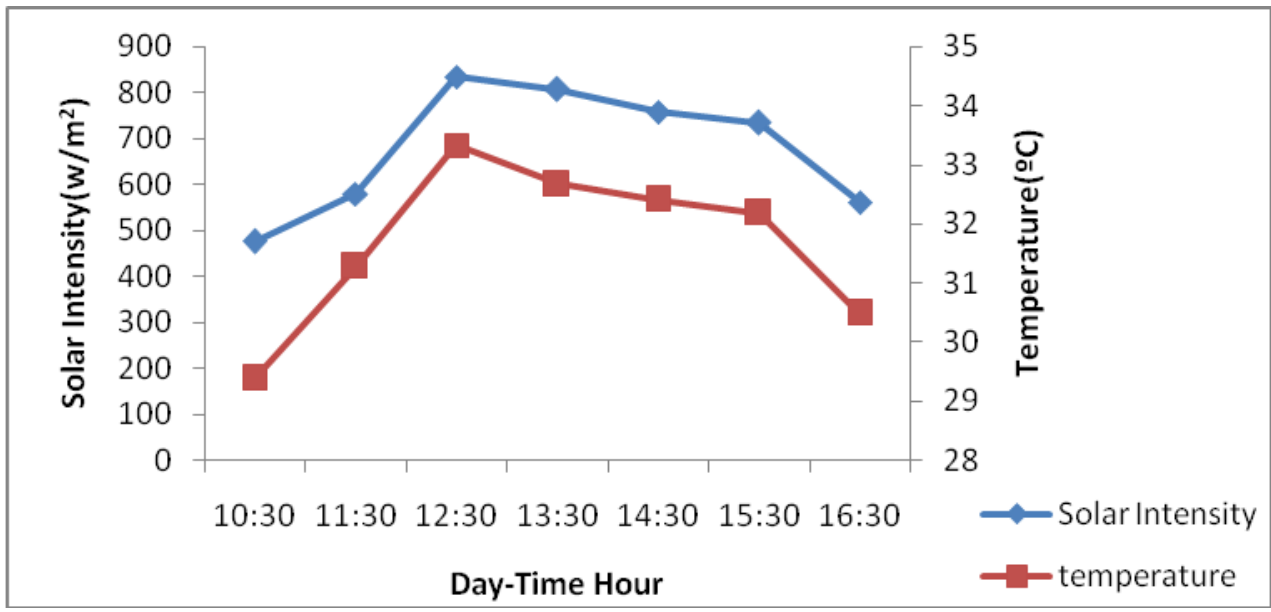

Fig.4 Variation of DC power output power with respect to temparature

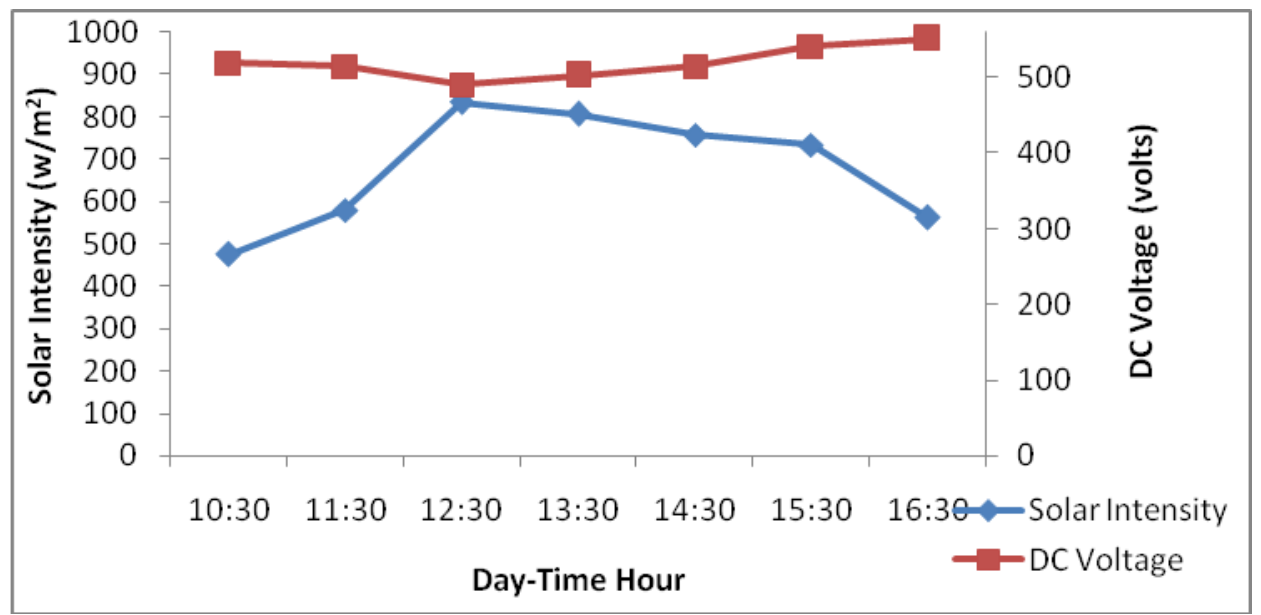

Fig.5 Variation of discharge with respect to solar intensity

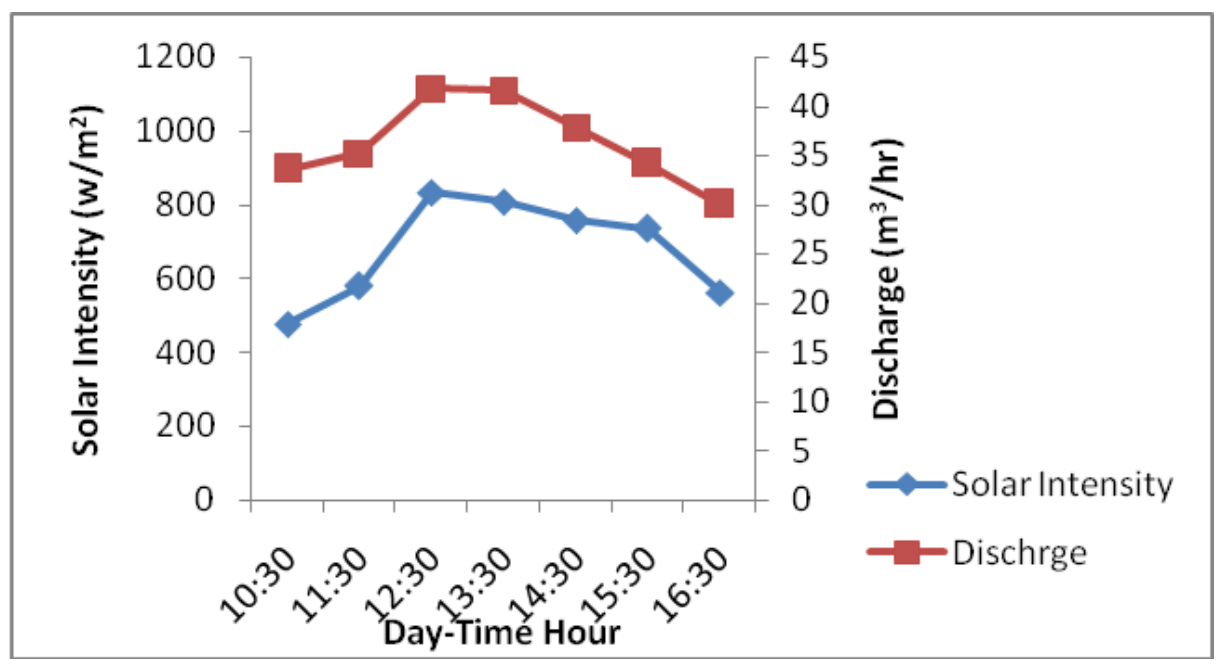


Fig.6 Variation of discharge with respect to relative humidity

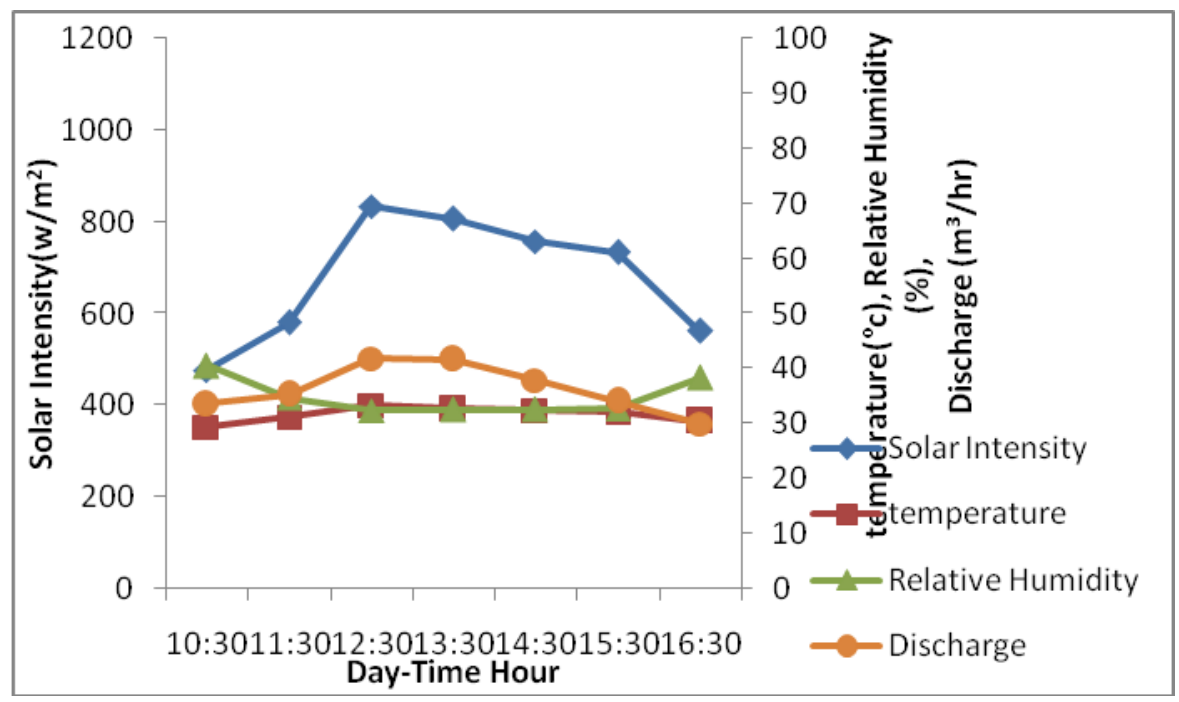

The solar PV water pumping unit was installed and tasted in test site at university of agricultural sciences, College of Agricultural Engineering Raichur, Karnataka having latitude of $16^{\circ} 15^{\prime}$ north. Longitude of $77^{\circ} 21^{\prime}$ east and after evaluation of $389 \mathrm{~m}$ above mean sea level which is considered as north eastern dry zone of Karnataka. The solar PV pumping system consists of 32 modules of 255.5 watt each and $7.5 \mathrm{hp} \mathrm{Dc}$ centrifugal mono block solar pump. During morning condition the minimum and maximum solar intensity were observed in the range of 476 to $580 \mathrm{~W} / \mathrm{m}^{2}$. However, corresponding variation in the voltage produced were in the range from 519.19 to 515.14 volts. Whereas during noon condition minimum and maximum solar intensity were observed in the range of 562 to $834 \mathrm{~W} / \mathrm{m}^{2}$. However, corresponding variation in the voltage produced in the range 490.82 to 550.89 volts. During morning condition under normal (solar intensity low) condition, power increased from 7580.18 to 7783.76 watts. The power produced from the PV array was dependent on the incident solar radiation. The pump delivered maximum discharge in morning condition $35.23 \mathrm{~m}^{3} / \mathrm{h}$ for an average solar intensity of $580 \mathrm{~W} / \mathrm{m}^{2}$ performance of photovoltaic module by drawing I-V curve analysis during morning condition. The pumping efficiency varied from 25.27 to $29.28 \%$. During noon conditions (when solar intensity is high), the power varies from 7848.22 to 7051.40 watts. The pump delivered maximum discharge in the noon conditions $41.82 \mathrm{~m}^{3} / \mathrm{h}$ for a solar intensity of $834 \mathrm{w} / \mathrm{m}^{2}$. Performance of photovoltaic module was made by drawn I-V curve analysis during noon condition. The pumping efficiency varied from 66.07 to $56.60 \%$.

During morning condition (when solar intensity is low), pv system produced voltage in the range of 519.19 to 515.14 volts, when solar radiation in the range of 476 to 580 $\mathrm{w} / \mathrm{m}^{2} \mathrm{a}$ t $10: 30$ to $11: 30 \mathrm{am}$ on clear days. Whereas, during morning conditions pv system produced current in the range of 14.60 to 15.11 amps. During noon conditions pv array produced maximum power of 7848.32 watts at 12:30 pm while, Vmp and Imp were observed 490.82 volts and 15.99 amps respectively at solar radiation $834 \mathrm{w} / \mathrm{m}^{2}$.It was observed during noon condition pump delivered maximum discharge of $41.82 \mathrm{~m}^{3} / \mathrm{h}$ when solar intensity of $834 \mathrm{w} / \mathrm{m}^{2}$ at $12: 30 \mathrm{pm}$ and produced minimum discharge of $33.56 \mathrm{~m}^{3} / \mathrm{h}$ in morning condition. It was 
observed that in morning conditions pumping efficiency varied from 57.56 to $62.46 \%$ while, in the noon conditions pumping efficiency from 66.07 to 56 .

\section{References}

Abdulkadir and Muhamadu. 2012. Design construction and performance evaluation of solar water pump. Department of mechanical engineering, vol-2: 711-718.

Alexander L carrier. 2012. Solar panel design and general performation. Pp. 1-19.

Ammar, M., Ridha, F.M. and Ammar, B.B., (2012). Data acquisition system for photovoltaic water pumping system in the desert of Tunisia, Procedia Engineering, 33: 268-277.

Andrada, P., and castro, J., 1997. Solar photovoltaic water pumping system using a new linear actual. vol-5: 3-27.

Babosa, S., and Tiba, C., (2001). Photovoltaic water pumping systems. Federal University, Pp. 1653-1662.

Bhubaneswary,. P., Iniyanb, S. and Ranko, G. (2011). A review of solar photovoltaic technologies, Renewable and sustainable energy reviews, 15: 1625 1636.

Brion, D., Vick and Nolan clark R., 2011. Performance of wind electric and solar$\mathrm{Pv}$ water pumping system for watering livestock. Agricultural Research Service, conservation and protection. Pp.198-203.

Chikkaire, J., Nnadi, F.N., Nwakwsi, R., N., Anyoha, N.O., Aja, O.O., Onoh, P.A and Nwachukwu, C.A. (2010). Solar energy application for agriculture, Journal of agricultural veterinary sciences. 2: 58-62.

Eker, B. (2005). Solar powered Water pumping system, Trakia Journal of sciences, 3(7): 7-11.
Fred, L. and Pichet, D., (1994). Estimation the performance a photovoltaic pumping system, Journal of Solar energy, 52(2):215-219.

Gonkale, S.D. and Datta, R.L., (1973).Solar energy application in India, Solar energy, 14(3): 321-326.

Hamid, M., Metwally, B. and Wagdy, R.A., (1996). Dyanamic performance of directly coupled photovoltaic water pumping system using Dc shunt motor, journal of energy conservation and management, 37(9):1407-1416.

Hegazi, A., Awady, M.N., Hegazi, M.M and Elgindy, R.W., 2010. Performance evaluation of locally assembled solar powered irrigation pump. Misr J. Ag, Eng., 27(1): 141-150.

Hossain, M. A., Islam, M.S., Chowdhury, M.M.H. and bari, M.S., 2011.Performance evaluation of 1.68Kwp Dc operated solar pump with auto tracker using micro controller based data acquisition system. International conference on mechanical engineering, vol-2: 1-5.

Illanes, R., Dc Francisco, A., Torrest, J.L., De Blas, M. and Appelbaum, J., (2003). Comparative study by simulation of photovoltaic pumping system with stationary and pollar tracking arrays, progress in photovoltaic: Research and applications, 11: 453-465.

Jafar, M. (2000). A model for small-scale photovoltaic solar water pumping, Journal of Renewable Energy, 19(1-2): 85-90.

Janaka, J. and Chandraratna, H.T., 2006. Performance evaluation of solar water pumps. International conference, 421424.

Kang'au. S.N., Home, P.G. and Gathenya, J.N., 2011. Evaluation of the performance of small holder pumped irrigation systems. Biomechanical and 
environmental engineering, vol-13(4): $1-13$.

Martina, C. and Hartmut, H., (1998). A Ripple based maximum power point tracking algorithm for a single-phase, grid connected photovoltaic system, solar energy, 63(5): 277-282.

Oguka, C.U. (2009). Performance characteristics of controlled separately excited Dc motor. The specific Journal of Science and Technology, Pp. 67-74.

Rajb Baran Roy. 2012. Design, and performance analysis of the solar Pv Dc water pumping system. Electrical and Electronic Engineering, 3: 403-412.

Satya Prasanth Yalla, Ramesh, B. and Ramesh, A., 2013. Autonomous solar powered irrigation system. International Journal of Engineering Research and Application, vol-3 issue-1: 60-65.
ShivLal, Pawan kumar and Rajeev, Rajora., 2013. Techno-economical analysis of solar photovoltaic based submersible water pumping system for rural areas of an Indian state. Science Journal of Energy Engineering, Pp. 1-4.

ShivLal, Pawan Kumar and Rajeev, Rajora, 2013. Performance analysis of photovoltaic based submersible water pump. International Journal of Engineering and Technology., 5: 552560.

Sui Tha sing and Mi sundar Mon. 2013. Design, and for performance analysis of solar water pumping system. International conference on environmental protection and renewable energy, Pp. 147-151.

\section{How to cite this article:}

Priyanka, V. Raghavendra, Vijaykumar Palled and Veerangouda, M. 2018. Performance Evaluation of Solar Water Pumping System. Int.J.Curr.Microbiol.App.Sci. 7(05): 133-142. doi: https://doi.org/10.20546/ijcmas.2018.705.017 